\title{
Relationship Between Glass Ceiling Syndrome and Self-Efficacy; in Health Sector
}

\author{
Taşkın Kılıç
}

\begin{abstract}
Objective of the study: In the line management of the busines life, women's taking a back seat more than men, in related literature, is entitled to "Glass Ceiling" term. Objective of this study is to specify the perception of Glass Ceiling of women work in health sector in proportion to men work in same sector, also, to identify relation between self-efficacy term which has important effects on career success and Glass Ceiling syndrome. Methodology of the study: 100 managers, 100 employee work in the institutions of the ministry of health and 100 new graduate (not assigned yet management trainee), in total, 300 people form the research sample. The research was conducted by face-to-face survey. The obtained data were subjected to analysis in SPSS software. Result of the study: as a result of the research, it has been found that women have more Glass Ceiling syndrome according to men. Between self-efficacy and glass ceiling syndrome, scientifically no meaningful results have been obtained on age and title.
\end{abstract}

Keywords: Glass Ceiling Syndrome, queen bee syndrome, self-efficacy

\section{Introduction}

Although the percentage of women in today's business world increases every day, this increase does not reflect evenly in the top management point. According to the "Women in Business and Management" report published in January 2015 by International Labour Organization (ILO), (ILO Global Report, 2015), women constitute $40 \%$ of the business life. Women also owns $30 \%$ of companies in the world. However, according to research conducted by the ILO in 126 countries; there are only three countries which have more women executive manager in proportion to men. These are; Jamaica, 59,3\%, Colombia, 53,1\%, Saint Lucia, 52,3\%. The last three countries in the list are; Jordan 5. 1\%, 4. 9\% in Algeria, Pakistan 3,0\%. According to the report; considering all levels of managers (lower-medium and upper), Turkey, with a rate of $12,2 \%$, ranks 95th among 126 countries. Turkey, in this category, ranks behind the countries such as Iran, $14,6 \%$, Malaysia, 21,5\%, and Uganda $20,2 \%$. Worldwide average (private and public sector) ratio of female managers (upper, middle and lower level) is $24 \%$ (Ceylan, 2014), at this rate, women fall behind men. In health sector which has formed our study sample, although $55 \%$ of employees are women, the ratio of women in management positions is around $25 \%$ (Public Hospitals Association annual Statistics, 2014; www. attyiz. biz. tr). Women remaining in the background compared to men in management positions of business life has aroused interest of both countries and scientific researchers since 1980 and reports and research have been conducted in this regard. The disadvantage suffered by women has been termed with "Glass Ceiling" concept in related literature.

Glass Ceiling (GC) concept first has been pronounced in 1984 by Gay Bryant, Working Woman magazine editor. Bryant has stated women's reaching a certain point and getting stuck there with "Glass Ceiling" concept (Boyd,2008).

American Federal GS Comission has defined this concept as an invisible and inaccesible (unidentified) factor affecting the use of some of the capabilities of women and minorities and preventing their rise to the top steps like manager(Federal Glass Ceiling Commission,1995). GC concept has been defined by Wirth (2001) as an invisible and artificial barriers created by organizational prejudices and forms, affecting women having position in senior management. From this description; what is desired to be explained with GC Metaphor is the uncertainty, abstraction of the encountered problems which can not be fully defined.

Reasons of Glass Ceiling concept: when related literature is examined, reasons which cause Glass Ceiling Syndrome are dealt with in different studies and in different extends. When these researches are combined to a common base, three main factors causing Glass Ceiling syndrome come into prominence (Hofstede,2001: Bolat and others, 2012, Cleveland and others, 2000; Bartol, 2003; Weyer, 2007; Örücü and others, 2007). 
These are; biological and genetic factors (length, strength, endurance, such as hormone structure and fertility); sociopsychological and personal factors (self-efficacy, lack of role models, stereotypes, etc.); cultural Factors (masculinefeminine society and corporate culture of culture and so on)

The other factor that affects women getting top management stages is self-efficacy (Bolat and others, 2012). self-efficacy is "belief of individual in his own capacity to identify and carry out the necessary actions to manage the possible states" (Bandura, 1997,3). Individuals who have high self-efficacy perception set themselves high goals and show the effort needed to achieve those goals. On the other hands, individuals who have low self-efficacy perception abandon easily against failure or difficulty. Individuals who haven't been able to get enough of self-efficacy and motivaton throughout their lives, because lacking of necessary self-confidence and courage to manage large organizations and to enter risky jobs, they cannot attempt to do business this area. This situation arises as a result of lack of self-efficacy.

Looking at the issue in the light of this information, in both the education system and living, women and men gain selfefficacy in different fields. Since the early ages, occupations such as management and entrepreneurship have been performed by men, their self-efficacy in this area stands out compared to women and women gain self-efficacy in different areas of life. In this regard, self-efficacy level of women and men are different from each other and as a consequence of that this situation poses an obstacle for women entering the ambitious tasks such as management and leadership. In brief; women who couldn't get enough mativation and self-efficacy from past experince, because lacking of necessary selfconfidence and courage to manage large organizations and to enter risky jobs, they cannot attempt to do business this area. This situation arises as a result of lack of self-efficacy.

When examined related literature, it has been seen a limited number of studies about relationship between Glass Ceiling perception of workers in the health sector and self-efficacy. In this regard in this study, exposure levels of Glass Ceiling perception of manager, employee working in health sector and management trainees of new graduated from health management department of the university will be comparatively dealt with.

Thus, effects of Glass Ceiling perception and self-efficacy concept will be revealed in the health institutions proportionately more women work than man. In this respect, the study is such as to illuminate a problem that is experienced in the field.

\section{Research}

\section{Hypothesis of the research}

H1. There is a relationship between Glass Ceiling and self-efficacy.

H2. Glass Ceiling perceptions differ by gender significantly.

H3. According to degree Glass Ceiling and self-efficacy perceptions differentiate significantly.

Sample of the research: male and female employess working in the Ministry of Health institutions form the research sample. Total 100 working women and men, total 100 men and women manager and total 100 schoolgirl and schoolboy, in total 300 people has participated to the research. Research was conducted by face-to-face survey. The obtained data were subjected to analysis in SPSS software.

The Research Data Collection and Analysis Method: In research, to evaluate Glass Ceiling concept, 10 worded survey which was used for a study in 2012 by Bolat and others is used; to evaluate self-efficacy perception, developed by Schwarzer and Jerusalem (1981) and adapted to Turkish as Schwar and Jerusalem (1997) by Yeşilay, generalized selfefficacy 10-point scale is used. The 8 expression have been asked to determine the demographic characteristics. The obtained data were subjected to analysis using the SPSS program.

Findings and Comments Related to Data Research: In order to demonstrate the reliability of the scales, Cronbach's Alpha analysis has been used. The results has showed that Alpha coefficient was found to be in the 0.724 level, it has been observed that our scale is reliable. Those surveyed consists of $\% 50$ men and $\% 50$ women. When it has been looked at the findings relating to the age group of the participants, it has been determined that at most $37,3 \%$ participants were in the range 18 to 24 age range. Those surveyed, $49,4 \%$ are married and $50,6 \%$ are single. It has been seen that the majority of survey respondents $(64,0 \%)$ have graduate degree. When it has been looked at the titles of participants's findings, $33,3 \%$ of the participants are new graduate/not yet working, $33,3 \%$ of the participants are working and $33,4 \%$ of the participants are managerial staff. 


\section{Hypothesis Test Results}

H1: There is a significant relationship between Glass Ceiling concept and self-efficacy perception.

As a result of correlation test, since sig. results were 0,879 greater than 0,05 , there iss no significant relationship between the two concepts. Thus, the $\mathrm{H} 1$ hypothesis has been rejected.

H2: Glass Ceiling perceptions differ by gender significantly.

As a result of the independent sample $T$ test, sig. results were 0,000 smaller than 0,05 , the relationship between two concepts is significant. Thus, the $\mathrm{H} 2$ hypothesis has been accepted. When compared the Glass Ceiling perception of women and men, it appears women experience more Glass Ceiling perception than men. According to this result, the average for men is $50 \%$, women is $61 \%$.

H3: According to degree, Glass Ceiling and self-efficacy perceptions differentiate significantly.

As a result of Anova test, sig. results 0,287 were greater than 0,05 , Glass Ceiling perception does not differ significantly in term os titles. Thus, the $\mathrm{H} 3$ hypothesis has been rejected.

\section{Conclusions and Recommendations}

The research of related literature has listed many reasons that prevent women making career. One of the most important of these is the Glass Ceiling syndrome. In this study, the effect of Glass Ceiling syndrome on health workers has been examined according to self-efficacy, gender and titles. According to the results of the analysis; one of the three developed hypothesis was accepted, two of the three was rejected. According to this, Glass Ceiling perception varies significantly by gender. When compared to men, women are feeling more Glass Ceiling perception. These results are consistent with the results of many studies done before. Scientifically meaningful results has not been obtained in terms of self-efficacy and title variables.

\section{Suggestions:}

As a society,the place of woman in education and training should be placed importance on.

In community and particularly in business life, gender distinction shouldn't be made.

Awareness about women's career should be increased.

When women come to the manager position, it should be role model for the fellows.

\section{References}

[1] Bandura, A. (1997). Self-Efficacy: The Exercise Of Control. New York: Freeman.

[2] Bartol, K. K. (2003). Leadership and the glass ceiling: gender and ethnic group influences on leader behaviors at middle and executive managerial levels. The Journal of Leadership and Organizational Studies, 9(3), 8-19.

[3] Bolat, T; Bolat,O; Kılıç,T,2011; Career Self-Efficacy and Glass Ceiling Moderating Efect of work-Related Masculunity values- Interdisciplinary Journal of Contemporary Research in Business. (IJRB). Vol. 2. No:10: Ferruary-2011 ISSN:2073-7122 p. 57-68

[4] Boyd, Karen S. (2008). "GLASS CEILING. " Encyclopedia of Race, Ethnicity, and Society. Ed.. Thousand Oaks, CA: SAGE,. 549-52. SAGE Alınış Tarihi: 17. 09. 2015

[5] Ceylan,I. (2014). Türkiye'de kadın yönetici oranı geriledi, http://www. kariyer. net/ik-blog/turkiyede-kadinyonetici-orani-geriledi/ Erişim tarihi: 06. 09. 2015

[6] Cleveland, J. N., Stockdale, M., \& Murphy, K. R. (2000). Women and men in organizations: sex and gender issues at work. New Jersey: Lawrence Erlbaum Associates, Inc. 
[7] Federal Glass Ceiling Commission, (1995). Good for Business: Making Full Use of the Nation's Human Capital U. S. Glass Ceiling Commission Publications Key Workplace Documents 3-1-1995 Cornell University ILR School DigitalCommons, ILR

[8] Hofstede, G. (2001). Culture's consequences: comparing values, behaviors, institutions, and organizations across nations. (2nd ed. ). California: Sage Publications.

[9] http://www. attyiz. biz. tr/haber/4192/saglik-bakanligi-teskilatinda-yoneticilerin agilimlari. html

[10] Kamu Hastane Birlikleri İstatistik yıllığı 2014, http://rapor. saglik. gov. tr/kitap /2014/\#/59/zoomed

[11] ILO, Global Report, (2015). Women in business and management: gaining momentum / International Labour Office. Geneva: ILO, 2015

[12] Örücü, Edip, Recep Kııı̧ ve Taşkın Kılıç (2007) "Cam Tavan Sendromu ve Kadınların Üst Düzey Yönetici Pozisyonuna Yükselmelerindeki Engeller: Balıkesir ili Örneği”, Yönetim ve Ekonomi Dergisi, Yıl: 2007, Cilt: 14, Sayl: 2, s. 117-135

[13] Schwarzer, R. Jerusalem, M. (1981) The General Self-Efficacy Scale Http://Userpage. Fu-Berlin. De/Health/Selfscal. Htm Alıııs Tarihi 01. 12. 2012

[14] Weyer, B. (2007). Twenty years later: explaining the persistence of the glass ceiling for women leaders. Women in Management Review, 22(6), 482-496.

[15] Wirth, L. (2001), Breaking Through The Glass Ceiling: Women in Management, International Labour Office, Geneva.

[16] Yeşilay, A. Schwarzer, R. Jerusalem, M. (1997). Öz-Yeterlilik Ölçeği, http://userpage. fu-berlin. de/health/turk. htm, Alınış Tarihi:10. 12. 2012 